\title{
ASCORBIC ACID AND THE FORMATION OF NITRIC OXIDE IN HUMAN LEUKOCYTES
}

\author{
T.T. Zhumabaeva', Z. V. Kuropteva ${ }^{1}$, Zh.T.Moldaliev', \\ ${ }^{1}$ Institute of biochemical physics, Russian Academy of Sciences, Moscow, \\ ${ }^{2}$ Osh State University
}

DOI: https://doi.org/ 10.31435/rsglobal_ws/28022019/6352

\section{ARTICLE INFO}

Received: 20 December 2018

Accepted: 18 February 2019

Published: 28 February 2019

\section{ABSTRACT}

Ascorbic acid is involved in the formation of nitrogen oxide in leukocytes of humans and animals. It is an important role of the AA in maintaining the immune status of the organism.

\section{KEYWORDS}

Ascorbic acid, leukocyte, EPR

spectra, nitrozyl complexes of hem proteins, nitroxide synthases (NOS), the formation of nitric oxide.

Citation: T. T. Zhumabaeva, Z. V. Kuropteva, Zh. T. Moldaliev. (2019) Ascorbic Acid and the Formation of Nitric Oxide in Human Leukocytes. World Science. 2(42), Vol.1. doi: 10.31435/rsglobal_ws/28022019/6352

Copyright: (c) 2019 T. T. Zhumabaeva, Z. V. Kuropteva, Zh. T. Moldaliev. This is an open-access article distributed under the terms of the Creative Commons Attribution License (CC BY). The use, distribution or reproduction in other forums is permitted, provided the original author(s) or licensor are credited and that the original publication in this journal is cited, in accordance with accepted academic practice. No use, distribution or reproduction is permitted which does not comply with these terms.

It is now established that Ascorbic acid (AA) performs several important functions in the body: -reducing properties of AA do her perfect kosubstrate in monooxygenize hydroxylation reactions in the biosynthesis of collagen (hydroxylation of prolin and lysine residues), as well as in the reactions of hydroxylation, leading to education noradrenalin, serotonin, carnitin in animal brain. -as an oxidant, participates in the protection of both cytozolic and membrane component cells from oxidative damage by neutralizing the damaging action of peroxide radicals [1-4].

The main role of AA in metabolism is that it is the best (but not the only) factor, it is necessary to maintain iron-and copper-containing proteins in restored condition, in which they are most functionally active [5]. Human leukocytes can accumulate in the cytozolic to AA concentrations, which in 60-80 times higher than plasma concentrations [6.7]

However, despite the large amount of researches is still functional role of Leukocyte cells type AA remains unknown. Although experimentally established fact, that the content of AA in leukocytes high, could lead to the assumption that AA has played a major role in their physiological function.

Materials and methods. Human leukocytes obtained from peripheral blood of adult donors fax during natural sedimentation of blood at room temperature. During nearly 4 hours every 30 min collected from the cylinder with blood leukocyte layer formed on the surface of the section of plasma and erythrocyte settling layer using a plastic Pasteur pipettes. The collected cells are washed twice $0.9 \% \mathrm{NaCl}$ solution with the addition of $2 \%$ of cattle serum platelet removed by centrifugation at 200 $\mathrm{g}$ for $5 \mathrm{~min}[8]$.

Then the cells were resuspended concentration to $2.7 \times 10$. Of the washed sediments of leukocytes, smears were made, fixed, stained and the cellular composition was determined. The resulting suspension contained approximately $25 \%$ lymphocytes and $75 \%$ granulocytes (neutrophils). Were prepared two kinds of suspensions:

- leucocytes with the addition of Ascorbic acid $(12 \mathrm{~mm})$ in the tris-buffer $(20 \mathrm{~mm})$, 
- leukocytes, with the addition of tris-buffer $(20 \mathrm{~mm})$ without AC. The leukocyte suspensions were purged with argon for 5-7 min and incubated them in identical conditions at room temperature. At certain intervals were taken samples in teflon tubes with an internal diameter of $3 \mathrm{~mm}$ and a length of $30 \mathrm{~mm}$ and fast freeze them at the temperature of liquid nitrogen. Then the frozen solutions were pushed out of tube in liquid nitrogen and samples were obtained in the form of columns with a diameter of $3 \mathrm{~mm}$ and a length of $30 \mathrm{~mm}$.

Used «Sigma» company AA. Concentration of AA in cell suspension was $15 \mathrm{~mm}$. The cell suspensions were purged with argon for 5-7 min and incubated them under identical conditions at room temperature. At certain intervals samples were and quickly frozen them at a temperature of liquid nitrogen.

Registration of ESR spectra. The EPR spectra were measured with X-band X-band radio spectrometers ESR 300 from firm equipped with standard programs and ER-220D ("Bruker", Germany). The number of produced nitric oxide systems determined by the method of double integration of signals nitrozyl complexes hem-NO ESR signal and a reference. The standart was the solution in the water nitroxide radicals 4-(N,N-dimethyl-decilamin) - 2,2,6, and 6-tetramethylpiperidine-N-oxide in concentration- $10^{-5}$.

Results and discussion. Leukocytes and human blood. Suspensions were investigated human leukocytes in their incubation in the presence of Ascorbic acid and without it. ESR spectra are shown samples of human leukocytes incubated for for 19 hours at room temperature $(\sim 18-20)$ in the presence of the AA (fig. 1.1) and without the addition of AA (fig. 1.2). The ESR spectra of leukocytes incubated for with AA, recorded EPR signal resulting from the nitrozilnymi complexes gem-NO with triplets splitting an $=17$ gausses at $\mathrm{g}=2.01[9,10,19,22]$. Hemoglobin $\left(\approx 10^{-5} \mathrm{M}\right)$ has been preadded to the incubation medium as a trap for NO.

$\mathrm{AA}$ and the absence of these complexes in suspensions incubated for without AA indicates that under the influence of AA human leukocytes also produce nitric oxide.

Quantitative assessment showed that in these conditions, under the influence of AA in leukocytes produced $\sim 6 \times-8 \times 10^{7} \mathrm{NO}$ molecules per cell. It is known that NO synthesis by cells from L-arginine is carried out by special enzymes - NO- nitroxide synthases (NOS). To date, there are three types of NOS: endothelial nitroxide synthases (eNOS), neurological nitroxide synthases (nNOS) and inducible nitrite oxidase (iNOS). Inducible nitrite oxidase (iNOS) in macrophages activated a number of cytokines (such as interferon- $\gamma$, interleukins, etc.) and endotoxins [11-19]. AA also likely involved, directly or indirectly, it is in induction of iNOS in leukocytes.

In Figure 1. 2. And ESR spectra are human blood pecimens, incubated for for 6:00 pm in the presence of AA (fig. 2.1) and without it (fig. 2.2).

In the spectrum of blood with the AA also registered nitrozyl complexes of hem proteins by ESR signal-NO, indicating the formation of nitric oxide in the blood. The ESR spectra of blood samples incubated without adding of AA, is registered in the monitored range only ESR signal plasma protein ceruloplasmin g-factor 2.05 (fig. 2.2).

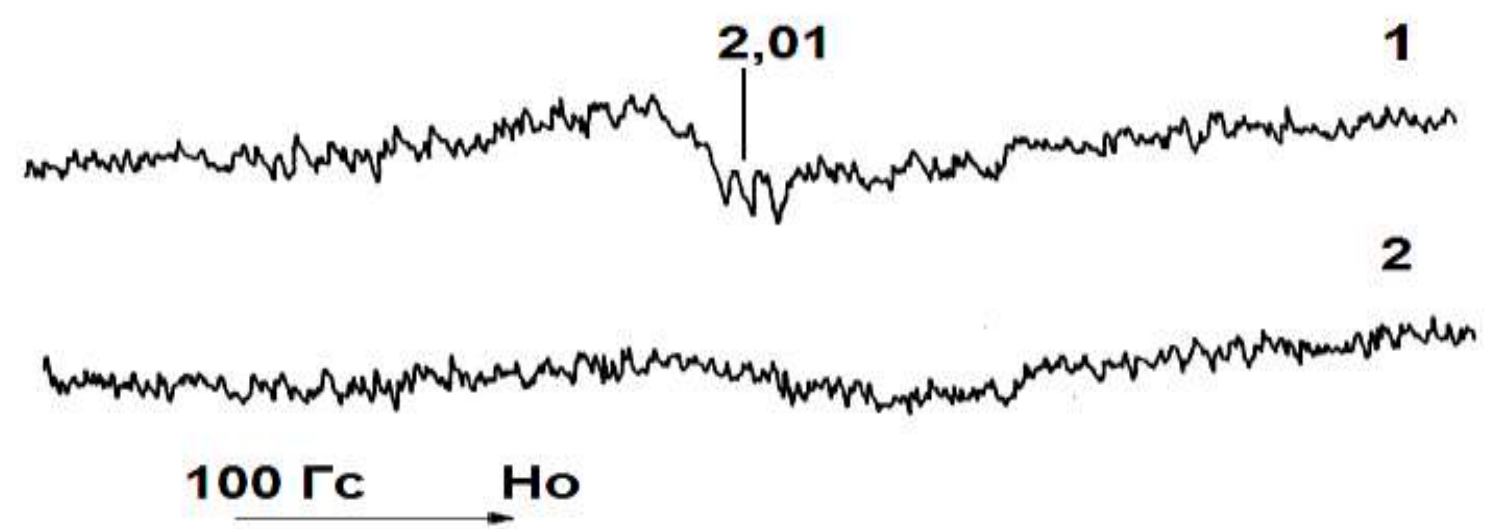

Fig. 1. ESR Spectra of samples of human leukocyte after 19 hours incubation at room temperature:

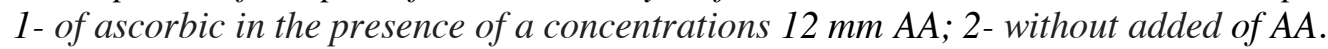

Conditions of registration: Power Over the treble $20 \mathrm{mw}$, amplitude of modulation of magnetic field in 5 gausses, temperature $77 \mathrm{~K}$, spectra of 1 and 2 recorded at the same enhancement. 
NO education in whole blood under the action of AA is also likely responsible, mainly leukocytes, so in erythrocytes, as we know, there are no production system NO (see figure. 2. B). Perhaps a minor contribution to the formation of NO in the blood could contribute and platelets.

Thus, the obtained data showed that AA is directly involved in the reaction, that triggers the formation of NO cells. Producing NO leukocytes may also participate in the implementation of immune control in blood (and the body), causing the death of pathogenic bacteria and tumor cells. That AA is able to support the body's immune system, is known for many years [1-5, 20.21]. But, the mechanism of action of AA while remained unclear. We believe that the induction of nitric oxide in leukocytes can be one of the main functions of AA in the body.

The mechanism of action of AA to the formation of nitric oxide in cells so far is unclear. But you can suggest two possible variants of its participation in the famous nitric oxide pathway involving NO-synthase from L-arginine. Firstly, the AA can play the same role as that of tetrahydrobiopterin $\left(\mathrm{BH}_{4}\right)$, and serve as the donor electrons on a plot linking $\mathrm{BH}_{4}$ [22-25].
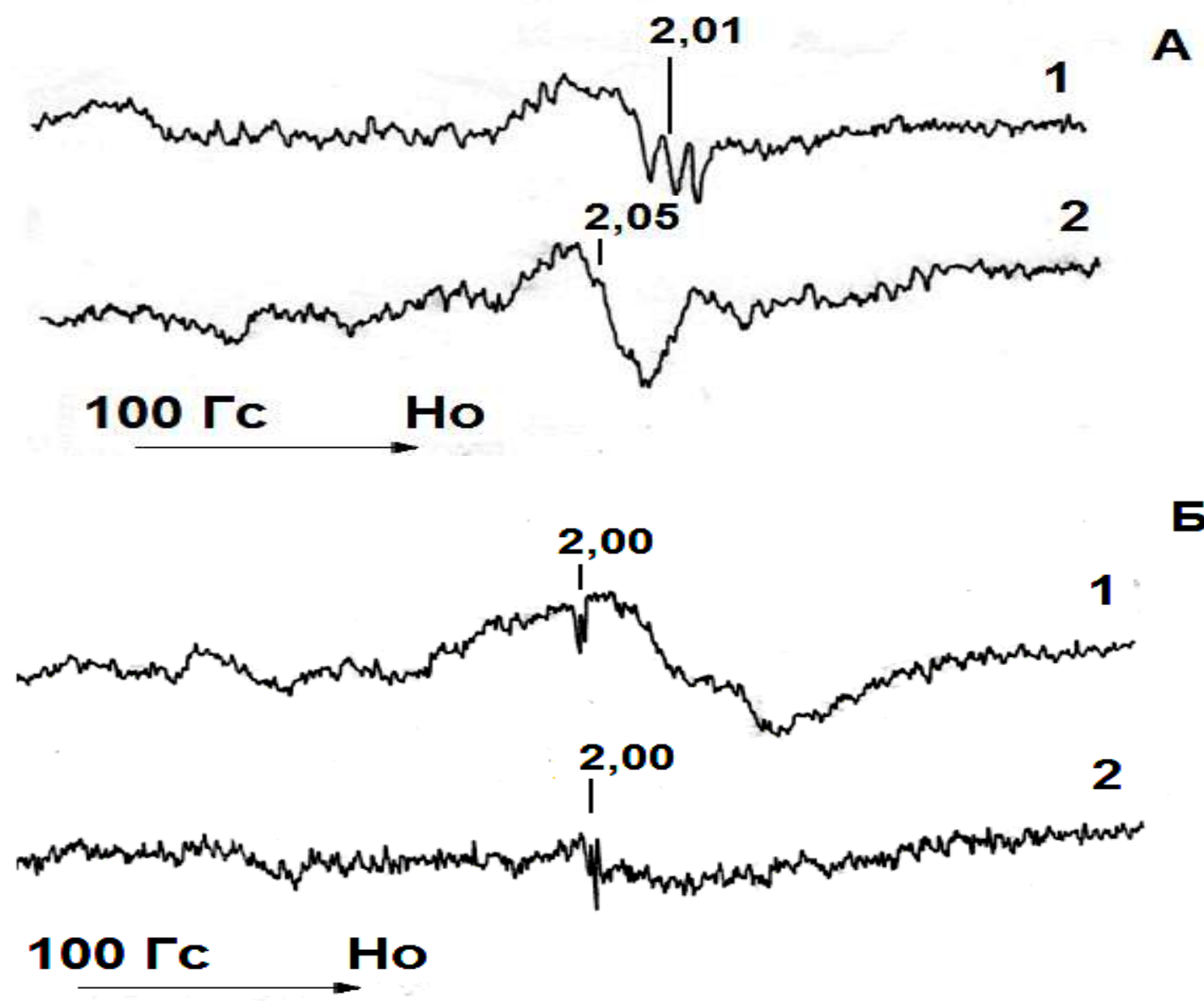

Fig. 2. EPR Spectra of samples of human blood (a) and (b) erythrocytes incubated for 24 hours at room temperature: 1- the presence of a concentration of $12 \mathrm{~mm} \mathrm{AA;2-without} \mathrm{the} \mathrm{addition} \mathrm{of} \mathrm{AA.}$

Conditions of registration are the same as in Fig. 1. 1.

Secondly, AA may participate in producing substrates NO-synthase, NADPH and in particular $\mathrm{BH}_{4}$. The second assumption is based on the available data in the literature about increasing the content of NADPH under the influence of the AA and the necessary participation in maintaining $\mathrm{BH}_{4}$ in restored condition. AA is needed to prevent irreversible oxidation $\mathrm{BH}_{4}$ in digidrobiopterin [22].

Conclusions. The research shows that Ascorbic acid is involved in the formation of nitrogen oxide in leukocytes of humans and animals. It is expected that is the participation of AA in the formation of nitric oxide in immunocompetent cells of humans and animals. Suggests, an important role of maintaining the immune status of the organism. 


\section{REFERENCES}

1. Enstrom J.E. Vitamin $\mathrm{C}$ in prospective epidemiological studies. In Vitamin $C$ in Health and Diseases (Packer L., and Fuchs G., eds). 1997. P.381-389, Marcel Dekker, Inc., New York.

2. Vinson J.A., Hu Shen-Ju, Jung Synah, Stanski A.M. A citrus extract plus AA decreases Lipids, lipid peroxdes, lipoprotein oxidative susceptibility, and atherosclerosis in hypercholes terolemic hamsters // J.Agr. and Food Chem. 1998. V.46. N4. P.1453-1459.

3. Carr A., Frei B. Does vitamin $\mathrm{C}$ act as a pro-oxidant under physiological conditions? // The FASEB J. 1999. V.13. P.1007-1024.

4. Levine M. New concepts in the biology and biochemistry of ascorbic acid. // N.Engl.J.Med. V.314, P.892902, 1986.

5. Halliwel B. Vitamin C: antioxidant or pro-oxidant in vivo? // Free Rad. Res. 1996. V.25. P.439-454.

6. Burns J.J. Missing step in man, monkey and guinea pig required for the biosynthesis of ascorbic acid. // Nature, 1957. v.180, p.553.

7. Rose R.C. Transport of ascorbic acid and other water-soluble vitamins // Biochim. Biophys Acta. 1988. V. 947. P. 335-366.

8. Beyur A. Separation of leucocytes from blood and bone marrow // Scand. J. Clin. Lab. Invest. 1968. V.21. Suppl. P.9713. Pauling L. Vitamin C and the Common Cold. San Francisco, California. 1970. Stone I.The Healing Factor, Vitamin C Against Disease, Grosset and Dunlap, New York. 1972.

9. Louro S.R.W., Ribeiro P.C., Bemski G. EPR spectral changes of nitrosyl hemes and their relation to the hemoglobin T-R transition // Biohimica and Biophysica Acta. 1981. V.670. N 1. P.56-63.

10. Szabo A., Perutz M.F. Equilibrium between Six- and Fife-Coordinated Hemes in Nitrosyl-hemoglobin: Interpretation of ESR Spectra // Biochem. 1976. V. 15, N 20. P. 4427-4428.

11. Moncada, S., Palmer, R.M.J., Higgs, E.A. Nitric oxide: physiology, pathophysiology and pharmacology. // Pharmacol. Rev., 1991. V.43. P.109-142.

12. Hebel J.M.., Marletta M.A. Macrophage nitric oxide synthase: relationship between enzyme-bound tetrahydrobiopterin and synthase activity // Biochemistry. 1992. V.31. P.7160-7165.

13. Schmidt H.H.H.W., Hofmann H., Ogilvie P. // The role of nitric oxide in physiology and pathophysiology. B.; Heidelberg: Springer, 1995. P.75-86.

14. Bredt D.S. et al. Cloned and expressed nitric oxide synthase structurally resembles cytochrome H-450 reductase.// Nature. 1991. V.351. P.714-718.

15. Knowles R.G., Moncada S. Nitric oxide synthases in mammals // Biochem. J. 1994. V.298. P.249-258.

16. Mayer B., John M., Heinzel B., et al. Brain nitric oxide synthase is a biopterin - and flavin-containing multi-functional oxide-reductase // FEBS Lett. 1991. V.288. P.187-191.

17. Feldman P.L., Griffith O.W., Stuehr D.J. The surprising life of nitric oxide.// C.I. E. N. 1993. Dtc.20. P.2636.

18. Heinrich P.C., Castell J.V., Andus T. Interleukin-6 and the acute phase response // Biochem. J., 1990, V.265. P.621-636].

19. Жумабаева Т.Т., Байдер Л.М., Куроптева 3.В. Высвобождение ионов железа из трансферрина под действием оксида азота. // Биофизика, 2000, Т.45, В.4, С.712-715

20. Levine M. New concepts in the biology and biochemistry of ascorbic acid. // N.Engl.J.Med. V.314, P.892902,1986

21. Девис М., Остин Ж., Патридж Д. Витамин С. Химия и биохимия. М. «Мир».1999. с.99.

22. Куроптева 3.В., Жумабаева Т.Т., Байдер Л.М., Володина Л.А. Аскорбиновая кислота и продуцирование оксида азота в Е. Coli. // ДАН РАН, 2000, Т.374. № 4. C.552-554.

23. Hibbs J. B. Jr., Vavrin Z. Taintor R.R. L-arginine is required for expression of the activated macrophage effector mechanism causing selective metabolic inhibition in target cells.// J. Immunol., 1987. V. 138. №2. P. 550-565.

24. Hibbs J.D., Taintor R.r., Vavrin Z. Macrophage cytotoxicity: role for L-arginine deiminase and imido nitrogen oxidation to nitrite. // Sciences. 1987. V.235, P.478-486.

25. Weitzberg E., Lundberg J.O.N. Nonenzymatic nitric oxide production in humans. // Nitric oxide: Biology and Chemistry. 1998. V.2. N2. P. 1-7. 